\title{
Measuring the dimensionality of human resource management: The perspective of Malaysian SME owner-managers
}

\author{
Nazlina Zakaria ${ }^{a^{*}}$, Khairol Anuar Ishak ${ }^{a}$, Darwina Arshad ${ }^{a}$, Nor Azimah Chew Abdullah ${ }^{a}$ and \\ Norzieiriani Ahmad ${ }^{a}$
}

${ }^{a}$ School of Business Management, Universiti Utara Malaysia, Kedah, Malaysia

\begin{tabular}{l}
\hline C H R O N I C L E \\
\hline Article history: \\
Received: November 26, 2017 \\
Received in revised format: \\
March 31, 2018 \\
Accepted: April 4, 2018 \\
Available online: \\
April 5, 2018 \\
\hline Keywords: \\
Human Resource Management \\
(HRM) Practices \\
Small and Medium Enterprises \\
(SMEs)
\end{tabular}

\section{A B S T R A C T}

\begin{abstract}
Understanding that the measurement of HRM construct in Small and Medium Enterprises (SMEs) context is relatively critical, this study aims to assess the validity and reliability of HRM measurement based on the SME owner-managers' perspective in the Malaysian context. Following a data collection from 95 SME owner-managers, a confirmatory factor analysis was performed to investigate the factorial validity and reliability of the HRM measurement. The finding indicates that the measurement model was acceptable in consideration of the evidences of adequate reliability, convergent validity and discriminant validity. This study will be beneficial for future researchers, entrepreneurs and policy makers in better understanding to the value of HRM practices towards boosting the SMEs performance.
\end{abstract}

C 2018 by the authors; licensee Growing Science, Canada

\section{Introduction}

Human resources play a vital role in the organization's operation and success (Abdullah et al., 2009). According to Hassan (2010), and Osman et al. (2011) the revolution of a new era of business implementation, including SMEs, practices such as e-business, globalization, and technological advancement need human resources (employees) to have the capability to face many challenges. Specifically, organizations attempt to add value to their human resources (Arokiasamy \& Ismail, 2009) as well as manage the resources through a personnel department as a way of increasing their organizational performance (Abdullah et al., 2009; Ahmad \& Schroeder, 2003; Osman, \& Galang, 2011; ). Human resource management (HRM) is the process of managing human resources in an organization, and it refers to aligning those practices with business or corporate strategies (Panayotopoulou, 2003; Othman, 2008; Dhull \& Narwal, 2016). It can also be referred to as the policies, practices, and systems that influence the behavior, attitudes, and performance of employees in an organization (Rowley et al., 2004). In other words, HRM helps the organization manage its employees parallel with the strategies of the organization in achieving higher performance and success (Othman, 2008).

\footnotetext{
* Corresponding author.

E-mail address: nazlina@uum.edu.my (N. Zakaria) 
Previous studies reported that different studies had used different HRM practices in explaining the effect of certain HRM practices on organizational performance, yet there is no consistency as to what HRM practices should be covered in the "best practices" system (Pfeffer, 1994). For instance, Delery and Doty (1996) claimed the increased use of 16 management practices in enhancing productivity and profitability. On the other hand, Huselid (1995) identified seven key strategic human resource practices. In contrast to individual practices, he examined 13 high performance work practices, or simply labeled as "best practices", and concluded that the organization that used sophisticated HR practices was significantly associated with turnover, organizational productivity and financial performance. In another study Ichniowski et al. (1997) utilized 13 innovative practices falling under seven categories corresponding to high-involvement practices to increase productivity and quality.

Despite the fact that there is a comprehensive list of HRM practice that can affect organizational performance, some difficulties in the interpretation of the HRM-performance relationship may occur. This is because not all HRM practices are able to affect organizational performance, either directly or indirectly (Cardon \& Stevens, 2004; Ahmad \& Schroeder, 2003; Ghosh \& Biswas, 2017). Indeed, recent researchers have started to select some specific HRM practices in examining the effects of HRM practices on organizational performance, particularly in the context of SMEs. In SMEs, HRM practices may be given less attention due to the limited size and resource availability (Klaas et al., 2000) and the SMEs are alleged to adopt HRM practices informally and incomprehensively (De Kok \& Uhlaner, 2001). Therefore, the selection of HRM practices needs to be scrutinized and adapted to the context of the SMEs. Accordingly, this article aims to test the dimensionality and assess the psychometric rigor of HRM construct as perceived by Malaysian SME owner-managers (Nadali et al., 2017).

\section{Literature Review}

There are three approaches used in studying HRM practices with regard to organizational performance are universalistic, contingency or configurational (Delery \& Doty, 1996; Youndt et al., 1996). The simplest form of theoretical model in HRM literature is the universal, or "best practices" perspective. Their researchers are micro-analytical in nature. According to Youndt et al., (1996), this perspective involves a direct relationship between HRM practices and performance, that is some HRM practices are hypothesized as constantly superior to others, and all organizations should adopt these best practices (Delery \& Doty, 1996). On the other hand, from the contingency perspective, the impact of HRM practices on firm performance is conditioned by strategic posture of organization. Researchers in the contingency approach dispute that in order to be effective, HRM practices that are applied by any organization must be coherent with other aspects of the organization. They have tried to explain the interaction between various HRM practices and specific organizational strategies as they are related to organizational performance (Youndt et al., 1996). In contrast to the "best practice" and contingency approach, the configurational perspective is interested on how the pattern of multiple HRM practices is related to organizational performance. Wright and McMahan (1992) argued that there was a pattern of intended human resource deployments and activities that can help to facilitate an organization to achieve its goals. In order to be effective, an organization must build up its HRM system so that it reaches both a horizontal and vertical fit. Horizontal fit refers to the internal consistency of the organization's HRM practices, and vertical fit refers to the congruence of the HRM system with other organizational characteristics such as firm strategies. Hence, in order to explain the process of examining HRM practices that are related to organizational performance, the researcher can comply with either of the previously discussed practices, or a combination of those three different approaches, which are universalistic, contingency, and configurational. This paper adopts the universalistic perspective for several reasons. Firstly, the universalistic perspective is suggested as the primary approach as most HR studies are centered on a holistic view of HRM practices and organizational performance. It highlights a set of practices used by all firm employees and the uniformity of these practices across firms. Secondly, this perspective enables researchers to examine the contribution of each HRM practice on 
organizational performance relative to each other. Thirdly, the universalistic or "best practices" approach has been more frequently used than other perspectives (Pfeffer, 1994; Huselid, 1995).

Numerous studies have attempted to explain universalistic predictions. For example, Carlson et al. (2006) found a positively significant impact of the use of five best HRM practices, namely, training and development, recruitment package, maintaining morale, use of performance appraisals, and competitive compensation on family-owned SME performance. They further studied the relationship between compensation designs and performance and found those firms that applied more cash incentive had more significant relationships with sales growth performance at every level in the organization. In addition, Jayawarna et al. (2007) found that training activities were consistently correlated with organizational performance. Drawing from the universalistic or "best practices" perspective, there are several combinations of HRM best practices that have been examined in the SMEs context. However, there is no agreement about which combination of practices is better. As an illustration, Subramaniam et al. (2011) adapted four practices; Nasution et al. (2011) utilized two practices; Osman and Galang (2011) applied nine practices; Daud and Mohamad (2010) explored six practices; Ngui et al. (2008) adapted four practices; Vlachos (2008) adapted six practices; Carlson et al. (2006) applied five practices and Cardon and Stevens (2004) analyzed six practices in their studies (see Table 1 for a summary of best HR practices used by different studies in SMEs).

\section{Table 1}

Summary of Best Practices in Human Resource Used by Different Studies in SMEs

\begin{tabular}{|c|c|}
\hline Author & HRM Practices \\
\hline Osman et al. (2011a) & $\begin{array}{l}\text { 1. HR planning } \\
\text { 2. Staffing } \\
\text { 3. Job work design } \\
\text { 4. Training and development } \\
\text { 5. Performance appraisal } \\
\text { 6. Compensation } \\
\text { 7. Employee relations and communication } \\
\text { 8. Health and safety } \\
\text { 9. Job satisfaction }\end{array}$ \\
\hline Subramaniam et al. (2011) & $\begin{array}{l}\text { 1. Compensation policy } \\
\text { 2. Information sharing } \\
\text { 3. Training and Development } \\
\text { 4. Job Security }\end{array}$ \\
\hline Nasution et al. (2011) & $\begin{array}{l}\text { 1. Job related } \\
\text { 2. Reward related }\end{array}$ \\
\hline Daud and Mohamad (2010) & $\begin{array}{l}\text { 1. Recruitment and selection } \\
\text { 2. Training and development } \\
\text { 3. Performance appraisal } \\
\text { 4. Preparation of payroll } \\
\text { 5. Communication with employees } \\
\text { 6. Administrative management of } \mathrm{HR}\end{array}$ \\
\hline Vlachos (2008) & $\begin{array}{l}\text { 1. Compensation policy } \\
\text { 2. Decentralization and self-managed teams } \\
\text { 3. Information sharing } \\
\text { 4. Selective hiring } \\
\text { 5. Training and development } \\
\text { 6. Job security }\end{array}$ \\
\hline Carlson et al. (2006) & $\begin{array}{l}\text { 1. Training and development } \\
\text { 2. Recruitment package } \\
\text { 3. Maintaining morale } \\
\text { 4. Performance appraisals } \\
\text { 5. Compensation }\end{array}$ \\
\hline Cardon and Stevens (2004) & $\begin{array}{l}\text { 1. Staffing } \\
\text { 2. Compensation } \\
\text { 3. Training and development } \\
\text { 4. Performance management } \\
\text { 5. Organizational change } \\
\text { 6. Labor relations } \\
\end{array}$ \\
\hline
\end{tabular}


However, this paper presents the selection of HRM practices which was based on the commitmentbased HRM configuration adapted from (Takeuchi et al., 2007). The selection of the HR practices was consistent with the adoption of innovative approaches to HRM practices, which are deemed to be similar to organizational concept of high-involvement or high-performance work system (Takeuchi et al., 2007; Guthrie et al., 2002; Vlachos, 2009; Way, 2002) or innovative HRM (Agarwala, 2003; Zheng et al., 2009). The commitment-based HRM practices contain several 'best practices' in the current literature of SHRM. Moreover, additional support for this explanation comes from Arthur (1994) in which he reported that organizations with commitment-oriented HR system have better manufacturing performance than organizational control HR system. Therefore, the selected HRM practices can enhance the study of performance.

Following, Takeuchi et al. (2007) adapted four HRM practices from Takeuchi et al. (2007) commitment-based HRM system, which consisted of compensation, performance appraisal, selection and training and development. This study also added the practices of communication and information sharing adapted from (Agarwala, 2003). The choice of five HRM practices was based on a list of research articles related to HRM and performance compiled by Boselie et al. (2005). There were 104 articles reviewed: training and development (83 articles), contingent pay and reward scheme (71 articles), performance management (including appraisal) (51 articles), recruitment and selection (50 articles), and communication and information sharing (32 articles). Having the most support across literatures, the researchers' choice of these five practices was justified.

Previous researchers similarly agreed that staffing, training and development, performance appraisal, compensation and communicating and sharing of information are the five key HRM practices (Youndt et al., 1996; Takeuchi et al., 2007; Snell \& Dean, 1992; Zacharatos, 2001). This is also consistent with the approach validated by Bowen and Ostroff (2004) who claimed that with regard to the assessment of employees on the important dimensions of HRM, researchers get a better understanding of the extent to which HRM practices probably affect the effectiveness of the organization. Therefore, it was expected that these five HRM practices could be closely associated with organizational innovation and organizational performance in the Malaysian SMEs. Therefore, within the context of this study and following Takeuchi et al., (2007) and, Agarwala (2003) HRM was conceptualized as a combination of a number of practices that are systematically designed to be aimed at improving SME effectiveness and yielding better performance outcomes. The practices considered were compensation, performance appraisal, selection, training and development, and communication and information sharing. The following discusses a complete measurement of HRM practices in detail.

\section{Methodology}

\subsection{Population and Sample Size}

This study focused on SMEs in manufacturing sectors, which referred to firms in manufacturing, manufacturing-related services and agro-based industries with full-time employees between 5 and not exceeding 150 in North Peninsular of Malaysia (Perlis, Kedah and Penang). The list of companies was based on the SME Corp. directory. The manufacturing sector was selected because it contributed to the highest growth of 7.6\% to SME GDP growth in 2011 in comparison to the agricultural and service sectors (each $6.4 \%$ ) (NSDCa) as well as much higher in average productivity than other sectors (NSDCb). Only 108 firms turned up as a sample and 95 usable questionnaires were analyzed. Respondents of this study were the owners/managers who were the top management of a firm. They were considered the representatives of the company and had the most extensive knowledge of the issues under investigation. 


\subsection{Instrument Development}

SMEs do implement HRM practices in Malaysia even though they tend to be basic in nature, (Osman \& Galang, 2011; Jayawarna et al., 2007; Nasution et al., 2011; Daud \& Mohamad, 2010) as discussed above. The researchers also conducted an informal interview with a few owners/managers of SME firms. Findings from the interview indicate that the organizations implemented HRM practices, but informally and at a very minimum level. As a result, the researchers selected only five HRM practices which are relevant to the Malaysian SMEs: communication and information sharing, compensation, performance appraisal, recruitment and selection, and training and development. The five HRM practices were measured using a five-point Likert scale, ranging from $1=$ "strongly disagree" to $5=$ "strongly agree". Each dimension is explained further in the following.

Compensation was assessed using a six-item measurement adapted from Takeuchi et al. (2017). The questions were developed to ask the respondents about compensation packages practiced by the organization including extensive benefit, high wages, performance-linked reward system, and skillbased pay. Performance appraisal was appraised using eight items, selection (five items) and training and development program (eight items) adapted from (Takeuchi et al., 2007). Communication and information sharing was measured using five items adapted from (Way, 2002). The questions were developed to ask respondents about the organization's practices in sharing information with employees, encouraging open and transparent communication among employees, organizing family gathering, supporting work environment, respecting employees' contribution, as well as ensuring fairness in management practices.

\section{Findings}

\subsection{Measurement Model- Confirmatory Factor Analysis}

Smart PLS 3.0 was used to analyze the data (Ringle et al., 2015). The first step involved the reliability and validity assessment of the measurement model using confirmatory factor analysis as shown in Fig. 1 and Table 2 . In confirming the measurement model, the convergent validity and discriminant validity was assessed. Factor loadings, composite reliability (CR) and the average variance extracted (AVE) were determined to assess the convergent validity. Table 2 displays the convergent validity, which revealed all the item loadings exceeded the recommended value of 0.7 (Hair Jr, 2014). The loadings range from 0.749 to 0.925 indicates that the constructs explained more than half of the variance in the observed variable. Any loadings below 0.7 were deleted, resulting in final AVE and CR above the cutoff value of 0.7 .

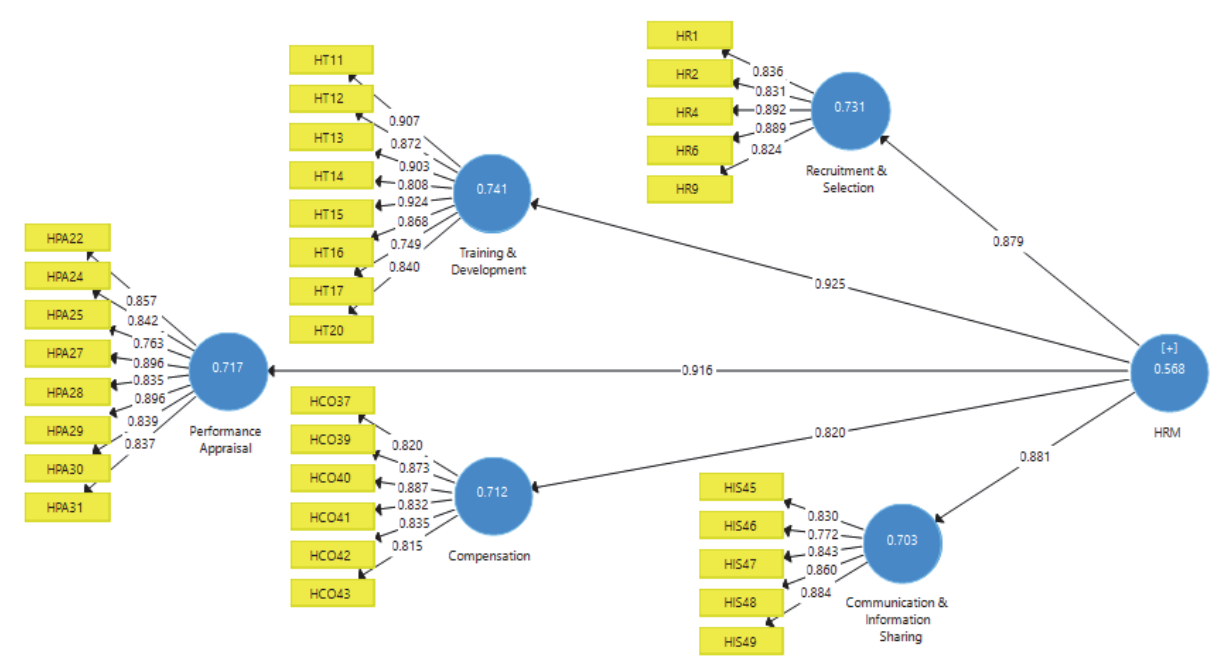

Fig. 1. Measurement Model of HRM Contructs 
The CR values highlight the degree to which the construct items represent the latent, which were in the range of 0.922 and 0.958 that exceeded the recommended value of 0 (Ringle et al., 2015). Furthermore, the AVE measures "the degree to which a latent construct explains the variance of its items", (Ringle et al., 2015) which is greater than 0.7. The AVE values of HRM practices are greater than the acceptable threshold of 0.7 which was in the range of 0.703 and 0.783 . From Table 2 , the results prove that the HRM practices constructs are valid measures based on their parameter estimates and statistical significance (Chow \& Chan, 2008).

Discriminant validity measures "the extent to which a construct is truly distinct from other construct, in terms of how much it correlates with other constructs, as well as how much indicators represent only a single construct" (Ringle et al., 2015). To assess the discriminant validity, the square root of the AVE is calculated which should be greater than each of the construct correlations (Ringle et al., 2015). Table 3 shows that all the square root of the AVE exceeded the correlations with other variable. In sum, the measurement model displayed adequate discriminant validity.

From all the findings, it can be reasoned that the measurement model was acceptable in view of the evidences of adequate reliability, convergent validity and discriminant validity.

Table 2

Results of Measurement Model

\begin{tabular}{|c|c|c|c|c|c|c|}
\hline First Order Construct & $\begin{array}{l}\text { Scale } \\
\text { Type }\end{array}$ & Item & Loadings & AVE & CR & $\begin{array}{l}\text { Item(s) deleted } \\
\text { due to low loadings }\end{array}$ \\
\hline \multirow[t]{5}{*}{ Recruitment } & Reflective & HR1 & 0.836 & 0.731 & 0.931 & HR3, HR5, HR7, \\
\hline & & HR2 & 0.831 & & & HR8, HR10 \\
\hline & & HR4 & 0.892 & & & \\
\hline & & HR6 & 0.889 & & & \\
\hline & & HR9 & 0.824 & & & \\
\hline Training & Reflective & HT11 & 0.907 & 0.741 & 0.958 & HT18, HT19 \\
\hline and & & HT12 & 0.872 & & & \\
\hline development & & HT13 & 0.903 & & & \\
\hline \multirow[t]{5}{*}{$(\mathrm{T} \& \mathrm{D})$} & & HT14 & 0.808 & & & \\
\hline & & HT15 & 0.924 & & & \\
\hline & & HT16 & 0.868 & & & \\
\hline & & HT17 & 0.749 & & & \\
\hline & & HT20 & 0.840 & & & \\
\hline Performance & Reflective & HPA22 & 0.857 & 0.717 & 0.953 & HPA21, HPA23, \\
\hline Appraisal & & HPA24 & 0.842 & & & HPA26 \\
\hline \multirow[t]{6}{*}{ (PA) } & & HPA25 & 0.763 & & & \\
\hline & & HPA27 & 0.896 & & & \\
\hline & & HPA28 & 0.835 & & & \\
\hline & & HPA29 & 0.896 & & & \\
\hline & & HPA30 & 0.839 & & & \\
\hline & & HPA31 & 0.837 & & & \\
\hline \multirow[t]{6}{*}{ Compensation } & Reflective & $\mathrm{HCO} 37$ & 0.820 & 0.712 & 0.937 & $\mathrm{HCO} 32, \mathrm{HCO} 33$, \\
\hline & & HCO39 & 0.873 & & & $\mathrm{HCO} 34, \mathrm{HCO} 35$, \\
\hline & & $\mathrm{HCO} 40$ & 0.887 & & & $\mathrm{HCO} 36, \mathrm{HCO} 38$ \\
\hline & & $\mathrm{HCO} 41$ & 0.832 & & & \\
\hline & & $\mathrm{HCO} 42$ & 0.835 & & & \\
\hline & & $\mathrm{HCO} 43$ & 0.815 & & & \\
\hline Communication & Reflective & HIS45 & 0.830 & 0.703 & 0.922 & HIS 44 \\
\hline and Information & & HIS46 & 0.772 & & & \\
\hline Sharing & & HIS47 & 0.843 & & & \\
\hline \multirow[t]{2}{*}{ (C\&IS) } & & HIS48 & 0.860 & & & \\
\hline & & HIS49 & 0.884 & & & \\
\hline
\end{tabular}


Table 3

Fornell-Lurker Criterion Analysis for Checking Discriminant Validity

\begin{tabular}{|c|c|c|c|c|c|}
\hline & C \& IS & $\mathrm{C}$ & PA & $\mathrm{R} \& \mathrm{~S}$ & $\mathrm{~T} \& \mathrm{D}$ \\
\hline Communication and Information Sharing (C \& IS) & 0.839 & & & & \\
\hline Compensation $(\mathrm{C})$ & 0.703 & 0.844 & & & \\
\hline Performance Appraisal (PA) & 0.729 & 0.726 & 0.846 & & \\
\hline Recruitment and Selection $(\mathrm{R} \& \mathrm{~S})$ & 0.747 & 0.601 & 0.754 & 0.855 & \\
\hline Training and Development (T \& D) & 0.784 & 0.647 & 0.785 & 0.836 & 0.861 \\
\hline
\end{tabular}

Diagonals (in bold) represent the square root of AVE while the other entries represent the correlation

Note: $* * p<0.01(\mathrm{t}>2.33)$

\section{Conclusion}

\subsection{Discussion and Implication}

This paper contributed to the validation of the dimensionality of HRM construct as perceived by Malaysian SME owner-managers. The rational of such validation was to identify a valid measure of HRM constructs in Malaysian SMEs. This is significant because most studies on HRM-performance linkages in Malaysia focused on large organizations and disregarded small organizations (Osman et al., 2011; Othman, 2008; Daud, 2006; Othman et al., 2001; Othman et al., 2001; Rowley \& Abdul-Rahman, 2007). On the other hand, HRM is equally important to smaller organizations as SMEs not a version of 'scaled-down' to large firms (Nguyen \& Bryant, 2004). According to Hassan (2010), the utilization and adoption of HRM practices are still limited in SMEs in comparison to multinational companies operating in Malaysia. Arokiasamy and Ismail (2009) pointed out that HRM practices are key for SME long-term survival. Therefore, the measurement of HRM constructs in large organizations could not be projected to SMEs. The limited attention in verifying the reliability and validity of HRM measurement in certain contexts can also lead to misleading conclusions.

The finding demonstrates that HRM construct in Malaysian SMEs consists of five key HRM practices such as communication and information sharing, compensation, performance appraisal, recruitment and selection, and training and development. In line with the previous researchers (e.g. Youndt et al., 1996; Takeuchi et al., 2007; Snell \& Dean, 1992; Zacharatos, 2001) our findings support the relevant five key HRM practices gains as HRM construct measurement in the SMEs context. In other words, the findings provide the methodological implications that HRM measures used in the present study were reliable and valid in the context of Malaysian SMEs manufacturing sector.

Overall, this paper provides a practical implication to the practitioners and policy makers in realizing the potential of HRM practices (communication and information sharing, recruitment and selection, compensation, training and development, and performance appraisal) to add value to their organizations. Thus, the findings can be used as a guide to assist SMEs owners/managers to identify which HRM practices that can be observed to improve the current HRM practices and their SME performance. Therefore, it is expected that the new empirical findings of this study can serve as a stimulus to the management of SMEs in order to take into consideration as well as to be more focus on managing human resources by having a formal HRM system and practices. This can be done through the mentormentee system with a large organization.

\subsection{Limitation and Future Research}

It should be noted that the findings of this study are subjected to SME owner-managers who are actively managing their own business. The applicability of these results beyond these kinds of businesses and personal engagement needs further investigation. In other words, the results need to be understood in the context and methodological concerns of the current study.

The limitations noted above offer opportunities for future research. To enhance generalizability, future 
research should expand the sampling frame by including other directories published by other agencies such as Department of Statistic Malaysia, Bank Negara Malaysia, and Federation of Malaysian Manufacturers (FMM). Moreover, future studies could be conducted in different SME sectors including primary agriculture and services throughout Malaysia. Conducting a study in the service sector is pertinent as this sector is poised to be the driver of future development, projected to reach a $65 \%$ share of GDP by 2020 (NSDCb).

The significance of the present study lies in the effort to recognize the applicability of the existing HRM practices measurement in Malaysian SME context. Thus, a practical tool is proposed to measure HRM practices that could be valuable for future research on SMEs. In conclusion, it is expected that the current findings could be used to offer better understanding to the dynamics affecting the performance of SMEs.

\section{Acknowledgments}

This research is funded by Universiti Utara Malaysia under the university grant scheme with S/O Code 13107.

\section{References}

Abdullah, Z., Ahsan, N., \& Alam, S. S. (2009). The effect of human resource management practices on business performance among private companies in Malaysia. International Journal of Business and Management, 4(6), 65.

Ahmad, S., \& Schroeder, R. G. (2003). The impact of human resource management practices on operational performance: recognizing country and industry differences. Journal of operations Management, 21(1), 19-43.

Agarwala, T. (2003). Innovative human resource practices and organizational commitment: An empirical investigation. International Journal of Human Resource Management, 14(2), 175-197.

Arokiasamy, L., \& Ismail, M. (2009). The background and challenges faced by the small medium enterprises. A human resource development perspective. International Journal of Business and Management, 4(10), 95.

Arthur, J. B. (1994). Effects of human resource systems on manufacturing performance and turnover. Academy of Management journal, 37(3), 670-687.

Boselie, P., Dietz, G., \& Boon, C. (2005). Commonalities and contradictions in HRM and performance research. Human resource management journal, 15(3), 67-94.

Bowen, D. E., \& Ostroff, C. (2004). Understanding HRM-firm performance linkages: The role of the "strength" of the HRM system. Academy of management review, 29(2), 203-221.

Cardon, M. S., \& Stevens, C. E. (2004). Managing human resources in small organizations: What do we know?. Human resource management review, 14(3), 295-323.

Carlson, D. S., Upton, N., \& Seaman, S. (2006). The Impact of Human Resource Practices and Compensation Design on Performance: An Analysis of Family-Owned SMEs. Journal of Small Business Management, 44(4), 531-543.

Chow, W. S., \& Chan, L. S. (2008). Social network, social trust and shared goals in organizational knowledge sharing. Information \& management, 45(7), 458-465.

De Kok, J., \& Uhlaner, L. M. (2001). Organization context and human resource management in the small firm. Small business economics, 17(4), 273-291.

Delery, J. E., \& Doty, D. H. (1996). Modes of theorizing in strategic human resource management: Tests of universalistic, contingency, and configurational performance predictions. Academy of Management Journal, 39(4), 802-835.

Daud, N. (2006). Unpublished PhD thesis, Universiti Sains Malaysia, Pulau Pinang. 
Daud, N., \& Mohamad, P. N. (2010, November). Exploring human resource practices in small and medium-sized enterprises in Malaysia: An empirical analysis. In Education and Management Technology (ICEMT), 2010 International Conference on (pp. 426-430). IEEE.

Dhull, S., \& Narwal, M. (2016). A state-of-art review on green supply chain management practices. Accounting, 2(3), 129-136.

Ghosh, I \& Biswas, S. (2017). A novel framework of ERP implementation in Indian SMEs: Kernel principal component analysis and intuitionistic Fuzzy TOPSIS driven approach. Accounting, 3(2), 107-118.

Guthrie, J. P., Spell, C. S., \& Nyamori, R. O. (2002). Correlates and consequences of high involvement work practices: the role of competitive strategy. International journal of human resource management, 13(1), 183-197.

Hassan, A. (2010). Linking quality assurance to human resource management: A study of SMEs in Malaysia. International Journal of Quality \& Reliability Management, 27(6), 641-657.

Hair Jr, F. J., Sarstedt, M., Hopkins, L., \& G. Kuppelwieser, V. (2014). Partial least squares structural equation modeling (PLS-SEM) An emerging tool in business research. European Business Review, 26(2), 106-121.

Huselid, M. A. (1995). The impact of human resource management practices on turnover, productivity, and corporate financial performance. Academy of management journal, 38(3), 635-672.

Ichniowski, C., Shaw, K., \& Prennushi, G. (1997). The effects of human resource management practices on productivity: A study of steel finishing lines. The American Economic Review, 291-313.

Jayawarna, D., Macpherson, A., \& Wilson, A. (2007). Training commitment and performance in manufacturing SMEs: Incidence, intensity and approaches. Journal of Small Business and Enterprise Development, 14(2), 321-338.

Klaas, B. S., McClendon, J., \& Gainey, T. W. (2000). Managing HR in the small and medium enterprise: The impact of professional employer organizations. Entrepreneurship Theory and Practice, 25(1), 107-124.

Nadali, S., Zarifi, S \& Shirsavar, H. (2017). Identifying and ranking the supply chain management factors influencing the quality of the products. Uncertain Supply Chain Management, 5(1), 43-50.

Osman, I., Ho, T. C., \& Carmen Galang, M. (2011). The relationship between human resource practices and firm performance: an empirical assessment of firms in Malaysia. Business Strategy Series, 12(1), 41-48.

Othman, R., Abdul-Ghani, R., \& Arshad, R. (2001). Great expectations-CEOs' perception of the performance gap of the HRM function in the Malaysian manufacturing sector. Personnel Review, 30(1), 61-80.

Osman, I., CF, T. H., \& Galang, M. C. (2011). Are human resource departments really important? An empirical study on Malaysian small and medium enterprises (SMEs) in the Service Sector. International Journal of Business and Management, 6(2), 147.

Othman, A. E. A. (2008, October). Strategic integration of human resource management practices: Perspectives of two major Japanese electrical and electronics companies in Malaysia. In Issues in Global Business and Management Research: Proceedings of the 2008 International Online Conference on Business and Management (IOCBM 2008) (p. 284). Universal-Publishers.

Panayotopoulou, L., Bourantas, D., \& Papalexandris, N. (2003). Strategic human resource management and its effects on firm performance: an implementation of the competing values framework. International Journal of Human Resource Management, 14(4), 680-699.

Pfeffer, J. (1994). Competitive advantage through people. California management review, $36(2), 9$.

Rowley, C., \& Abdul-Rahman, S. (2007). The management of human resources in Malaysia: Locallyowned companies and multinational companies. Management revue, 18(4), 427-453.

Rowley, C., Benson, J., \& Warner, M. (2004). Towards an Asian model of human resource management? A comparative analysis of China, Japan and South Korea. The International Journal of Human Resource Management, 15(4-5), 917-933.

Ringle, C. M., Wende, S., \& Becker, J. M. (2015). SmartPLS 3. Boenningstedt: SmartPLS GmbH, http://www. smartpls. com. 
Nasution, H. N., Mavondo, F. T., Matanda, M. J., \& Ndubisi, N. O. (2011). Entrepreneurship: Its relationship with market orientation and learning orientation and as antecedents to innovation and customer value. Industrial marketing management, 40(3), 336-345.

NSDC (2012a). Retrieved January, 30, 2013, from http://www.smecorp.gov.my/v4/node/2946

NSDC (2012b). Retrieved April, 27, 2015, from http://www.smecorp.gov.my/vn2/node/190

Ngui, K. S., Songan, P., \& Hong, K. S. (2008). Organisational Learning Capability of Malaysia SMEs: Examining the Effects of Entrepreneurial Orientation and Human-Capital Development Practices. Journal of Information \& Knowledge Management, 7(04), 219-230.

Nguyen, T. V., \& Bryant, S. E. (2004). A study of the formality of human resource management practices in small and medium-size enterprises in Vietnam. International small business journal, 22(6), 595-618.

Snell, S. A., \& Dean, J. W. (1992). Integrated manufacturing and human resource management: A human capital perspective. Academy of Management journal, 35(3), 467-504.

Subramaniam, C., Shamsudin, F. M., \& Ibrahim, H. (2011). Linking human resource practices and organisational performance: Evidence from small and medium organisations in Malaysia. Jurnal Pengurusan (UKM Journal of Management), 27, 32.

Takeuchi, R., Lepak, D. P., Wang, H., \& Takeuchi, K. (2007). An empirical examination of the mechanisms mediating between high-performance work systems and the performance of Japanese organizations. Journal of Applied Psychology, 92(4), 1069.

Vlachos, I. (2008). The effect of human resource practices on organizational performance: evidence from Greece. The International Journal of Human Resource Management, 19(1), 74-97.

Vlachos, I. P. (2009). High-performance workplace practices for Greek companies. EuroMed Journal of Business, 4(1), 21-39.

Way, S. A. (2002). High performance work systems and intermediate indicators of firm performance within the US small business sector. Journal of management, 28(6), 765-785.

Wright, P. M., \& McMahan, G. C. (1992). Theoretical perspectives for strategic human resource management. Journal of management, 18(2), 295-320.

Youndt, M. A., Snell, S. A., Dean, J. W., \& Lepak, D. P. (1996). Human resource management, manufacturing strategy, and firm performance. Academy of management Journal, 39(4), 836-866.

Zheng, C., O'Neill, G., \& Morrison, M. (2009). Enhancing Chinese SME performance through innovative HR practices. Personnel Review, 38(2), 175-194.

Zacharatos, A. (2001). Unpublished doctoral thesis, Queen's University, Kingston, Ontario, Canada.



(C) 2018 by the authors; licensee Growing Science, Canada. This is an open access article distributed under the terms and conditions of the Creative Commons Attribution (CC-BY) license (http://creativecommons.org/licenses/by/4.0/). 